\title{
USING BROCCOLI PLANT WASTES IN SHEEP RATIONS
}

\author{
Yasmim M.M. Mahmoud \\ Anim. Prod. Res. Inst ARC, Ministry of Agric., Dokki, Giza, Egypt.
}

(Received 15/3/2016, accepted 10/4/2016)

\section{SUMMARY}

$\mathrm{T}$ he objective of this work was to determine the effect of inclusion different levels of broccoli wastes in lamb rations on their productive performance, nutrient digestibility, feeding value, physiological and hematological parameters, rumen fermentation and also the economical efficiency. Twenty four growing male crossbred lambs (50\% Finland $+50 \%$ Rahmani) aged 3 months after weaning with averaged live body weight (LBW) $16.80 \pm 0.82 \mathrm{~kg}$ were randomly assigned into three similar groups (8 lambs each) using randomized complete block design. Three experimental diets were formulated as the first group was served as (control) (R0) and fed the concentrate feed mixture (CFM) according to recommendations of NRC (1989) plus the rouphage portion that consisted of $50 \%$ berssem hay and $50 \%$ wheat straw, while the diets of the second (R1) and third (R2) groups were including broccoli waste at 20 or $40 \%$ levels in replacing to berssem hay, respectively. Results of digestibility coefficients, showed no significant effect due to experimental treatments was noticed for digestion coefficients of DM, OM, CF and EE. The digestibility of CP and NFE and subsequently feeding values in terms of TDN and DCP were almostly significant higher with tested rations than control one. Final live body weight and daily weight gain were increased $(\mathrm{P}<0.05)$ significantly with increasing broccoli by-product levels. Lambs fed diets containing broccoli by-product rations led to an increases $(\mathrm{P}<0.05)$ significantly the TDNI compared with those fed the control diet. However, the best $(\mathrm{P}<0.05)$ feed conversion expressed as $(\mathrm{DMI})$ and $(\mathrm{TDNI})$ was occurred with $\mathrm{R} 2$, while the poorest one was found with the control one $(\mathrm{R} 0)$. Lambs in $\mathrm{R} 2$ showed significantly the highest $(\mathrm{P}<0.05)$ concentrations of total protein, albumin and Triglyceride, and those in R1 recorded the highest globulin, creatinine and cholesterol, while those in R1 and R2 had the highest AST and ALT activity compared with the (control) one R0. The concentration of urea was not significantly affected by treatments. Rumen $\mathrm{pH}$ value and Total volatile fatty acids (TVFAs) concentration were increased $(\mathrm{P}<0.05)$ and concentration of $\mathrm{NH} 3-\mathrm{N}$ was decreased $(\mathrm{P}<0.05)$ with increasing broccoli by-product. Lambs in R2 showed the highest value of price of daily gain, economical efficiency and relative economic efficiency as well as the lowest value of average daily feed cost compared with R0 (control) one. Haematological characteristics including RBCs, WBCs and others were also investigated.

Keywords: lambs, broccoli wastes, digestibility, growth performance, blood parameters, haematological characteristics, rumen activity.

\section{INTRODUCTION}

Because of the currently increasing cost of protein feed ingredients, this effort were carried out to use untraditional feed ingredients to participate in facing protein shortage problem and to decrease the feeding costs as well. Low dietary protein requirements may cause an imbalance in the body metabolism and growth performance and they are often at the expense of the proportion of fiber in the diet. Broccoli byproduct (Brassica oleracea) that belonging to the family Brassicaceae used as untraditional feed ingredients in the form of dried whole plant (Ahuja et al., 2011). Broccoli is a rich source of chemo protective molecules including glucosinolates, which considered a class of organic compounds that contain sulfur and nitrogen (Omirou et al., 2009), which often approaches $1 \%$ or more of their dry weight (Assayed and Abd El-Aty 2009). Selenium fortified broccoli has been proposed as a functional food for cancer prevention, based on its high glucosinolates content (Hsu et al., 2011). USDA (2011) reported that this food is low in saturated fat, and very low in cholesterol. It is also a good source of protein, thiamin, niacin, pantothenic acid, calcium, iron, and selenium and a very good source of vitamin A, Vitamin C, riboflavin, vitamin B6, folate, magnesium, phosphorus, potassium and mangnese. These materials are often regarded as crop remains and a small percentage is used without treatment in animal feeds. 
Recently, recovery and bioconversion of vegetables residues to high-value compounds has been receiving great attention (Mahro and Timm 2007). Presents an alternative to utilize the broccoli residues produced in the field, which constitutes the largest volume of vegetable and represents a problem for the farmer, with respect to its handling and disposal Olga et al. (2009). The same author also, indicated that drying is a viable alternative to utilize broccoli crop residue. There are many varieties of green leafy vegetables which are rich in micronutrients, but are usually discarded or not used for human consumption. Broccoli leaves are one of them, which are available at no cost and rich in all the macronutrient. It is an exceptionally nutritious vegetable with a variety of potential uses (Madhu and Anita Kochhar 2014). Ibrahim, et al. (2011) recorded that replacement alfalfa hay with broccoli by-product at $3 \%$ or $6 \%$ in rabbit diets was significantly $(\mathrm{P}<0.05)$ increased digestibility coefficients of (DM, CP and $C F)$ and feeding values (TDN and DCP) compared to control diet; however, it had no significant effect on digestibility coefficients of OM, EE and NFE. The ingestion of substantial amount of glucosinolates may be causing a deleterious effect to animal health and production (Tripathi and Mishra 2007). Mueller et al. (2012) recommended that piglets groups received broccoli extracts (BE) additives positively influenced weight gain and feed conversion in week 1 . Over the whole trial period no significant differences in performance parameters existed between the tested groups and control one that fed diet without additive. This study aimed to investigate the effect of broccoli by-product in replacing berssem hay by 20 or $40 \%$ on digestibility, growth performance of lambs, blood biochemical, hematological characteristics and rumen fermentation activity.

\section{MATERIALS AND METHODS}

The current work was carried out at Sakha Animal Production Research Station, Animal Production Research Institute, Agricultural Research Center, Ministry of Agriculture during the period from March to August 2016.

\section{Animals and feeding trial}

Twenty four growing male crossbred lambs (50\% Finland+50\% Rahmani) were used in this study with average body weight $(16.80 \pm 0.82 \mathrm{~kg})$ at initial point of the trial. The animals were housed in groups ( 3 groups of 8 lambs each) according to their body weight and age for growth trial that lasted for 180 days. Animals were weighed biweekly before morning feeding (after $17 \mathrm{~h}$ fasting period) to record the body weight and to calculate the average daily body gain and feed efficiency.

Ingredient and chemical composition of the experimental diets are shown in Table (1). The daily amounts of concentrate feed mixture (CFM) were introduced for all animals' groups according to recommendations of NRC (1989). The CFM was adjusted biweekly according to the change in animal's LBW, while the roughage portion of the control group was consisted of 50\% wheat straw (WS) and 50\% berseem hay $(\mathrm{BH})$ where the same was offered at $1 \%$ of LBW. The diets were offered individually to animals twice daily in two equal portions at $8.00 \mathrm{am}$ and $4.00 \mathrm{p} . \mathrm{m}$ to cover the total nutrient requirements. Lambs in first group (control) were fed the diet without any replacement (R0). While the other two groups (R1 and R2) were including broccoli by-products at 20 and $40 \%$ levels in replacing of $(\mathrm{BH})$, respectively.

\section{Digestibility trials}

Three digestibility trials were carried out using three rams for each ration consequently. They were placed in metabolic cages to determine digestion coefficients and feeding values of the experimental rations. Each trials lasted for four weeks where the first three weeks were as a preliminary period followed by one week for feces collection. Sheep were fed twice daily at $8.00 \mathrm{a} . \mathrm{m}$ and $4.00 \mathrm{p} . \mathrm{m}$ and water was offered freely. Weights of feed intake and feces were recorded and representative composite samples were prepared and stored at $-20{ }^{0} \mathrm{C}$ until chemical analysis. Feedstuffs and feces samples were dried at $70^{\circ} \mathrm{C}$ for $24 \mathrm{hrs}$ and then ground to pass through a $1 \mathrm{~mm}$ screen and its chemical composition were determined according to A.O.A.C. (1990).

\section{Rumen fermentation}

At the end of the digestibility trials, rumen liquor samples were individually collected after 6 hrs of the morning meal on two successive days. A sample of $100 \mathrm{ml}$ liquor was collected using a rubber stomach tube, strained through three layers of cheese cloth and the acidity was immediately measured by $\mathrm{pH}$ meter (Orin-Res- EARH, model 30). Ammonia-N was immediately determined by the micro-diffusion 
method according to Conway (1963). The rest of strained rumen liquor sample was kept in clean glass bottle, top-dressed with few drops of toluene and paraffin oils, covered with a rubber stopper and stored at $-18{ }^{\circ} \mathrm{C}$ until total VFA's determination. It was determined according to Warner (1964).

\section{Blood parameters}

At the end of the experimental period, blood samples were collected from the jugular vein of animals at $8.00 \mathrm{am}$ hrs before morning feeding ( 3 in each group) in two clean sterile tubes for each animal. The $1^{\text {st }}$ blood samples were centrifuged at 3000 r.p.m for 15 minutes and then plasma was separated and stored at $-20^{\circ} \mathrm{C}$ till chemical analysis. Plasma was used for determination total protein (Armstrong and Carr 1964), total albumin (Doumas et al., 1971) and globulin concentration was calculated as the difference between total protein and albumin. Plasma Aspartate (AST) and Alanine (ALT) aminotransferase activity were estimated according to procedures of Reitman and Frankel (1957). Total cholesterol was determined according to Allian et al. (1974) using bio Merieux test kits, plasma triglyceride was determined according to Wahlefeled (1974), creatinine according to Henry et al. (1974) and urea was measured according to (Patton and Crouch 1977). All biochemical blood constituents were determined using spectrophotometer (Spectronic 21 DUSA) and commercial diagnostic kits (Combination, Pasteur Lap.). The $2^{\text {nd }}$ blood samples were collected in heparinized tubes to obtain whole blood samples for determined hematological parameters including mean of corpuscular volume (MCV\%) using microhaematocrit centrifuge at 4000 r.p.m for 15 min (Mitruka and Rawnsley 1977), haemoglobin concentration using cyanomethemoglobin technique (Mitruka and Rawnsley 1977). Red blood cells (RBCs) and white blood cells (WBCs) counts were immediately estimated per $\mathrm{mm}^{3}$ from fresh blood using haematocytometer according to Mitruka and Rawnsley (1977).

\section{Statistical analysis}

The experimental data were statistically analysis according to Sndecor and Cochran (1980) using SAS program (1999). Difference among means between groups were determined using Duncan multiple range test (Duncan 1955).

\section{RESULTS AND DISCUSSION}

\section{Chemical composition of the experimental diets:}

Chemical composition of the experimental feed ingredients, CFM, WS, BH and BBP are presented in Table (1). Data showed that BBP had higher contents of crude protein $(24.86 \%)$ and ash (16.23\%), while the WS had lower CP $(3.56 \%)$ and ash $(8.89 \%)$ comparing to those of BH. While, the BBP had a lower content of fiber $(12.95 \%)$ compared with that of $\mathrm{BH}(33.33 \%)$. These results are in harmony with those obtained by Alpuche-Solis and Paredes-Lo'pez (1992) who found a relatively high protein content in florets flours $(36.6 \mathrm{~g} / 100 \mathrm{~g}$ dry weight) and stalks flours (18.6 g/100 g dry weight). Additionally, they also reported the protein level measured in whole plant flour (23.2 to $32.0 \mathrm{~g} / 100 \mathrm{~g}$ dry weight) of four cultivars of broccoli. The results obtained by Ibrahim et al. (2011) recorded strongly similarities in chemical composition between broccoli by-product and lucern hay being 15.19, 25.04, 1.52, 45.96 and $12.29 \%$ for CP, CF, EE, NFE and ash for lucern hay, corresponding 14.26, 23.87, 2.35, 45.96 and $13.56 \%$ for broccoli by-product, respectively. Also, slightly differences respecting the contents of NDF, ADF, ADL and cellulose were recorded between the two ingredients. The same authors suggested that this great similarity confirms that the existence of any significant results must be attributed to the medicinal substances or the bioactive compounds of broccoli. Gerendas et al. (2008) pointed that glucosinolates represent bioactive compounds of Brassica vegetables whose health promoting effects. In more recent study, Hu et al. (2012) recorded higher CP content (27.13\%) and lower CF content (8.85\%), than those obtained in the present study (Table 1) for broccoli stem and leaf meal on dry basis. They were also confirmed that broccoli by-product had significant concentrations of Vit. E and $\mathrm{C}, \mathrm{Ca}$ and $\mathrm{P}$ minerals, as well as most valuable amino acids like Methionin, Lysine, Cystine, Threonine, Leucine, Isoleucine, Arginine, Phenylalanine, Valine, Tryptophan and Tyrosine.

\section{Digestibility and feeding values}

The digestibility coefficients and feeding values of experimental rations of lambs are presented in Table (2). The obtained results indicated that no significant effect due to the dietary treatments was noticed for digestion coefficients of DM, OM, CF and EE. However, CP digestibility was significant higher with the high level of BBP-ration (R2) than that of the low BBP and control ones. Otherwise, 
NFE digestibility was significant higher with R1 than that of either R2 or R0. The feeding value as TDN seemed to be significant higher due to both tested rations compared to control one. Regarding DCP, its values were insignificant higher due to R1 and significant higher due to R2 in comparison with R0. In earlier study with rabbits (Ibrahim, et al. 2011) recorded that replacement alfalfa hay with broccoli by-product at $3 \%$ or $6 \%$ in rabbit diets was significantly $(\mathrm{P}<0.05)$ increased digestibility coefficients of (DM, CP and CF) and feeding values (TDN and DCP) compared to control diet; however, it had no significant effect on digestibility coefficients of OM, EE and NFE. These significant results may be due to the content of glucosinolates that are a class of organic compounds includes sulfur and nitrogen in broccoli which submit the digestion gastrointestinal conditions as $\mathrm{pH}$, temperature, enzyme and chemical conditions as observed by Vallej et al. (2004). Additionally, Madrid et al. (2002) indicated that the extent of by-product digestion and their characteristics of ruminal fermentation support the broccoli, Citrus peel and melon can be characterized as high-degradable feeds for ruminants.

Table (1). Chemical analysis of the experimental concentrate feed mixture, wheat straw, berseem hay, broccoli by-product and experimental rations (on DM basis, \%).

\begin{tabular}{lcccccc}
\hline Item & DM & CP & CF & EE & NFE & Ash \\
\hline Concentrate feed mixture (CFM) & 90.70 & 16.10 & 11.58 & 3.86 & 55.78 & 12.68 \\
Wheat straw (WS) & 90.00 & 3.56 & 46.78 & 1.67 & 39.10 & 8.89 \\
Berseem hay (BH & 90.00 & 13.33 & 33.33 & 2.33 & 41.23 & 9.78 \\
Broccoli by-product (BBP) & 92.50 & 24.86 & 12.95 & 1.16 & 44.80 & 16.23 \\
Experimental rations: & & & & & & \\
R0 & 90.35 & 12.27 & 25.82 & 2.93 & 47.97 & 11.01 \\
R1 & 90.48 & 12.85 & 24.80 & 2.87 & 45.91 & 11.33 \\
R2 & 90.60 & 13.43 & 23.78 & 2.81 & 43.85 & 11.65 \\
\hline
\end{tabular}

*Ingredients (CFM): 31.5 yellow corn, 24.0 cotton seed meal, 40.00 wheat straw, 3.0 molasses,

0.5 mineral premix and $1 \%$ salt (as fed), calculated according to Feed Composition Tables for animal and poultry feedstuffs used in Egypt (2001).

*RO, control ration, $R 1$, with $20 \%$ broccoli by-product and $R 2$, with $40 \%$ broccoli by-product.

Table (2). Digestion coefficients and feeding values of the experimental rations.

\begin{tabular}{lcccc}
\hline \multirow{2}{*}{ Item } & \multicolumn{3}{c}{ Experimental rations } & \multirow{2}{*}{ \pm S.E } \\
\cline { 2 - 4 } Digestibility, \% & R0 & R1 & R2 & \\
DM & & & & \\
OM & 67.04 & 70.78 & 67.18 & \pm 1.34 \\
CP & 66.53 & 71.23 & 66.69 & \pm 1.35 \\
CF & $50.65^{\mathrm{b}}$ & $55.86^{\mathrm{b}}$ & $64.38^{\mathrm{a}}$ & \pm 2.20 \\
EE & 48.11 & 49.80 & 49.17 & \pm 1.18 \\
NFE & 80.70 & 81.89 & 82.39 & \pm 2.32 \\
Feeding values , \% & $79.18^{\mathrm{b}}$ & $85.73^{\mathrm{a}}$ & $75.76^{\mathrm{c}}$ & \pm 1.47 \\
TDN & & & & \\
DCP & $58.07^{\mathrm{b}}$ & $64.18^{\mathrm{a}}$ & $62.37^{\mathrm{a}}$ & \pm 1.22 \\
\hline
\end{tabular}

$a, b$ and $c$ means in the same row with different superscripts are significantly $(P \leq 0.05)$ different.

$S E=$ Standard error

*RO, control ration, R1, with $20 \%$ broccoli by-product and $R 2$, with $40 \%$ broccoli by-product.

\section{Growth measurements}

The effect of broccoli by-product inclusion in the diets on growth measurements during the experimental period are presented in Table (3). Final live body weight and average daily weight gain were significantly higher with broccoli diets R1 and R2 compared with control one R0, being the differences were not significant between the tested treatments R1 and R2 in these items. These results are in agreement with those obtained by (Ibrahim, et al. 2011) who found that rabbits fed $6 \%$ broccoli byproduct replacing to lucern hay in their diet led to significantly $(\mathrm{P}<0.05)$ improvement in the final body weight and daily gain compared to control diet that free from broccoli by-product. On the other hand, 
( $\mathrm{Hu}$, et al. 2011) showed that the increasing dietary supplementation at $0,30,60$ and $90 \mathrm{~g} / \mathrm{kg}$ of dried broccoli stems and leaves meal (BSLM) had no effect $(\mathrm{P}>0.05)$ on productive performance of laying hens. While, Mueller et al. (2012) recommended that piglets groups received broccoli extracts (BE) additives positively influenced weight gain and feed conversion in week 1 . Over the whole trial period no significant differences in performance parameters existed between the tested groups and control one that fed diet without additive. Recently, Yi et al. (2015) concluded that replacing concentrate mixture with $20 \%$ pelletized broccoli by-products had no adverse effects on rumen fermentation, but increased milk production numerically and increased milk fat content significantly in lactating dairy cows. The increased use of broccoli by-product in the future would be beneficial for developing a more efficient use of resources and make ruminant milk production more environmentally friendly. Generally, Madrid et al. (2002) suggested that the effective use of by-products from agricultural industries as feedstuffs is dependent on several factors. These include the production, nutrient composition in relation to the nutrient requirements of the available animals, processing cost, the uniformity of supply of the by-product and the marked availability of competitively priced feedstuffs. Large quantities of by-products are used in the ruminant's diet in agro-industrial areas (Gasa et al., 1989).

Table (3). Average daily gain, feed intake, feed conversion and economic efficiency of lambs fed the experimental rations.

\begin{tabular}{|c|c|c|c|c|}
\hline \multirow[t]{2}{*}{ Item } & \multicolumn{3}{|c|}{ Experimental rations } & \multirow{2}{*}{$\pm \mathrm{SE}$} \\
\hline & R0 & R1 & $\mathrm{R} 2$ & \\
\hline Initial BW (kg/h) & 16.80 & 16.80 & 16.80 & \pm 0.82 \\
\hline Final BW (kg/h) & $37.00^{\mathrm{b}}$ & $44.600^{\mathrm{a}}$ & $48.800^{\mathrm{a}}$ & \pm 1.93 \\
\hline Total gain $(\mathrm{Kg} / \mathrm{h})$ & $20.2^{\mathrm{c}}$ & $27.8^{\mathrm{b}}$ & $32^{\mathrm{a}}$ & \pm 0.982 \\
\hline Daily gain (g/h) & $112.24^{\mathrm{b}}$ & $154.44^{\mathrm{a}}$ & $177.78^{\mathrm{a}}$ & \pm 7.85 \\
\hline \multicolumn{5}{|l|}{ Feed intake $(\mathrm{g} / \mathrm{h} / \mathrm{d})$ : } \\
\hline Concentrate feed mixture (CFM) & 540 & 540 & 540 & \\
\hline Wheat straw (WS) & 270 & 270 & 270 & \\
\hline Berseem hay (BH) & 270 & 216 & 162 & \\
\hline Broccoli by-product (BBP) & - & 54 & 108 & \\
\hline DMI & 1080 & 1080 & 1080 & \pm 5.77 \\
\hline TDNI & $664^{\mathrm{c}}$ & $675^{b}$ & $686^{\mathrm{a}}$ & \pm 0.001 \\
\hline \multicolumn{5}{|l|}{ Feed conversion: } \\
\hline Kg DMI/ Kg gain & $9.63^{\mathrm{a}}$ & $7.00^{\mathrm{b}}$ & $6.08^{c}$ & \pm 0.101 \\
\hline $\mathrm{Kg}$ TDNI/ Kg gain & $5.92^{\mathrm{a}}$ & $4.37^{\mathrm{b}}$ & $3.86^{\mathrm{c}}$ & \pm 0.062 \\
\hline \multicolumn{5}{|l|}{ Economic efficiency } \\
\hline Average daily feed cost (L.E) & 1026 & 977.4 & 928.8 & \\
\hline Price of daily gain(L.E) & 4.04 & 5.57 & 6.40 & \\
\hline Economical return (L.E /h/d) & 3.01 & 4.6 & 5.47 & \\
\hline Relative economic efficiency(L.E /h/d) & 100 & 1.51 & 1.81 & \\
\hline
\end{tabular}

\section{Feed consumption, feed conversion and economical efficiency}

Feed consumption, feed conversion and economical efficiency data of lambs fed the experimental rations are presented in Table (3). Lambs fed diets containing broccoli by-product at different levels of diet led to an increased $(\mathrm{P}<0.05)$ significantly TDNI compared with those fed the control diet $(\mathrm{R} 0)$.

However, the best $(\mathrm{P}<0.05)$ feed conversion expressed as $(\mathrm{DMI})$ and $(\mathrm{TDNI})$ was occurred with $40 \%$ broccoli by-product replacement (R2), while the poorest one was found with the control one (R0).

Economic efficiency expressed as price of daily gain, economical efficiency and relative economic efficiency was positively affected with broccoli by-product supplementation (Table 3). Lambs in R2 showed the highest values of price of daily gain, economical efficiency and relative economic efficiency as well as the lowest value of feed cost compared with R0 (control) one. These results agreed with those obtained by (Ibrahim, et al., 2011) who reported that the highest value of net revenue, economical efficiency and relative economic efficiency as well as the lowest value of feed cost/ $\mathrm{kg}$ live body weight were recorded at the $90 \%$ protein requirements with $6 \%$ broccoli by-product replacement on the expense 
of lucern hay in the diet of growing rabbits. Also, (Madhu and Kochhar 2014) recorded that there are many varieties of green leafy vegetables which are rich in micronutrients, but are usually discarded or not used for human consumption. Broccoli leaves are one of them, which are available at no cost and are rich in the most needed macronutrient for the biological processes in animals' body. It is an exceptionally nutritious vegetable with a variety of potential uses. Earlier Yi et al. (2008) found that broccoli byproducts were possibly suitable feedstuffs because of their high protein content and low cost. They were found little effect on in vitro gas production and ruminal fermentation in ruminant diets after replacing soybean meal with pelletized broccoli residues.

\section{Blood Biochemical Parameters}

Blood plasma parameters of lambs are presented in Table (4) in which results revealed that significant differences $(\mathrm{P}<0.005)$ in the concentrations of total protein among dietary treatments being $4.58,5.27$ and $5.50 \mathrm{~g} / \mathrm{dl}$ for R0, R1 and R2, respectively. Albumin concentrations were significant higher with the high level broccoli by-product diet than the low broccoli by-product diet and control one. Lambs fed $40 \%$ broccoli by-product showed significantly the highest $(\mathrm{P}<0.05)$ concentrations of total protein, albumin and Triglyceride, while those in R1 recorded the highest globulin, creatinine and total cholesterol compared with the (control) one.

Table (4). Blood parameters of lambs fed the experimental rations.

\begin{tabular}{lcccc}
\hline \multirow{2}{*}{ Item } & \multicolumn{3}{c}{ Experimental rations } & \multirow{2}{*}{ \pm SE } \\
\cline { 2 - 4 } & \multicolumn{1}{c}{ R0 } & R1 & R2 & \pm 0.050 \\
Total protein (g/dl) & $4.58^{\mathrm{c}}$ & $5.27^{\mathrm{b}}$ & $5.50^{\mathrm{a}}$ & \pm 0.028 \\
Albumin (g/dl) & $2.55^{\mathrm{b}}$ & $2.64^{\mathrm{b}}$ & $3.13^{\mathrm{a}}$ & \pm 0.056 \\
Globulin (g/dl) & $2.03^{\mathrm{c}}$ & $2.63^{\mathrm{a}}$ & $2.37^{\mathrm{b}}$ & \pm 0.052 \\
Createnine (mg/dl) & $0.780^{\mathrm{b}}$ & $1.067^{\mathrm{a}}$ & $0.880^{\mathrm{b}}$ & \pm 1.500 \\
Urea (mmol/l) & 39.00 & 37.50 & 42.00 & \pm 1.24 \\
Cholesterol (mg/dl) & $61.00^{\mathrm{c}}$ & $83.00^{\mathrm{a}}$ & $74.00^{\mathrm{b}}$ & \pm 2.92 \\
Triglyceride (mg/dl) & $122.00^{\mathrm{b}}$ & $110.00^{\mathrm{c}}$ & $133.00^{\mathrm{a}}$ & \pm 0.638 \\
Activity of AST U/L & $15.00^{\mathrm{b}}$ & $22.33^{\mathrm{a}}$ & $20.33^{\mathrm{a}}$ & \pm 0.577 \\
Activity of ALT U/L & $7.00^{\mathrm{c}}$ & $11.00^{\mathrm{b}}$ & $13.00^{\mathrm{a}}$ & \pm \\
\hline
\end{tabular}

$a, b$ and $c$ means in the same row with different superscripts are significantly $(P \leq 0.05)$ different.

$S E=$ Standard error

*RO, control ration, R1, with $20 \%$ broccoli by-product and $R 2$, with $40 \%$ broccoli by-product.

Kummer et al. (1981) showed that blood plasma total protein and its fractions can be used as indicators to evaluate the ruminant nutritional status and physiological change. So, the increase in globulin production by the liver could reflect a good hepatic function of these animals and correlates very well with high immunity status of them (Grimimger 1986). In consistent with this point, it is of interesting to note that supplementing cow diets with different levels of natural feed additives had positively effects on their immunity status as corresponding to globulin increasing levels. Also, (Craig 1999) cleared that albumen as a one of the important proteins that keeps the osmotic pressure stable in the blood. Both albumen and globulin results reflect the ability of animals to store reserve proteins even after their bodies have reached maximum capacity of depositing tissues, (Stroev 1989). In contrary these results are in disagreement with those obtained by (Cox-Ganser et al., 1994) who revealed that, transfer of sheep from grazing grass to Brassica forage results in a reduction in plasma cholesterol. While, Human intervention studies have provided evidence that diets rich in cruciferous vegetables may modify plasma lipid and cholesterol profile (Aiso et al., 2014). While, (Charlotte et al., 2015) revealed that volunteers consuming of $400 \mathrm{~g} /$ week of high glucoraphanin (HG) broccoli over 12 week period had significant reduction in plasma low density lipoprotein-cholesterol (LDL-c) concentrations compared to 400g/week standard broccoli, but with no significant change in high density lipoprotein (HDL), total cholesterol (TC) or triglyceride (TAG). The results of present study revealed that concentration of urea was not significantly affected by treatments, while, activity of AST and ALT enzymes was significantly higher $(\mathrm{P}<0.05)$ for lambs received the two levels of broccoli by-product than those received (control) one. Physiologically, Hu et al. (2011) indicated that hepatic hydroxymethylglutaryl-coenzyme A (HMG-CoA) reductase activity was decreased $(\mathrm{P}<0.05)$ linearly and quadratically with increasing dried broccoli stems and leaves meal (BSLM) supplementation. 
Generally, the values obtained respecting blood constituents in this study indicate normal physiological and healthy status of all lamb groups.

\section{Blood Haematological Parameters}

Results of hematological parameters are presented in Table (5). There were significant $(\mathrm{P}<0.05)$ effect due to dietary treatments on most studied parameters. Counts of red and white blood cells, haemoglobin concentration, haematocrit $\%, \mathrm{MCV} \%$, were higher with lambs received $40 \%$ broccoli by-product, while the lower values were occurred with either those received $20 \%$ broccoli by-product or those of R0 (control) one. Otherwise, percentage of Mean Corpuscular Hemoglobin Concentration (MCHC) \%, was followed the opposite among dietary treatments. The leukocytes (lymphocytes and mesophils percentages) were significant higher in tested rations than control one, but the others (neutrophils and eosinophils) were followed the inverse trend.

The present results are supported by Mueller et al. (2012) who illustrated that haemogram of piglets in all groups indicated a good health status, no clinical abnormalities during the whole experiment, since no parameter laid outside the normal range, when the diet of broccoli group (BE) contained $0.15 \mathrm{~g} / \mathrm{kg}$ sulforaphane in form of a broccoli extract. So, The present study proved and due to the broccoli byproduct is rich in most microelements like micro/macroelements, vitamins as well as most valuable amino acids and thus an improvement in haematological parameters of lambs fed broccoli by-product-ration could be favourably recognized.

Table (5): Haematological parameters of lambs fed the experimental rations.

\begin{tabular}{lcccc}
\hline \multirow{2}{*}{ Item } & \multicolumn{3}{c}{ Experimental rations } & \multirow{2}{*}{ R S E } \\
\cline { 2 - 4 } & $9.05^{\mathrm{b}}$ & $8.80^{\mathrm{c}}$ & $9.38^{\mathrm{a}}$ & \pm 0.035 \\
Red blood cells (RBCs) $\times 10^{6} / \mathrm{ul}$ & $10.20^{\mathrm{b}}$ & $10.23^{\mathrm{b}}$ & $11.50^{\mathrm{a}}$ & \pm 0.107 \\
Haemoglobin (Hb), mg/dl & $21.03^{\mathrm{c}}$ & $23.00^{\mathrm{b}}$ & $26.00^{\mathrm{a}}$ & \pm 0.433 \\
Haematocrit (Hct), \% & $23.27^{\mathrm{b}}$ & $26.14^{\mathrm{a}}$ & $27.69^{\mathrm{a}}$ & \pm 0.541 \\
Mean Corpuscular Volume (MCV), \% & $11.27^{\mathrm{b}}$ & $11.63^{\mathrm{b}}$ & $12.30^{\mathrm{a}}$ & \pm 0.109 \\
Mean Corpuscular Hemoglobin (MCH), $\%$ & $48.62^{\mathrm{a}}$ & $44.57^{\mathrm{b}}$ & $44.27^{\mathrm{b}}$ & \pm 1.15 \\
Mean Corpuscular Hemoglobin Concentration (MCHC), \% & $1.40^{\mathrm{c}}$ & $1.77^{\mathrm{b}}$ & $3.09^{\mathrm{a}}$ & \pm 0.092 \\
White blood cells (WBCs) $\times 10^{3} / \mathrm{ul}$ & $49.00^{\mathrm{a}}$ & $28.00^{\mathrm{b}}$ & $30.00^{\mathrm{b}}$ & \pm 1.37 \\
Neutrophils (N), \% & $41.00^{\mathrm{b}}$ & $66.00^{\mathrm{a}}$ & $64.00^{\mathrm{a}}$ & \pm 1.56 \\
Lymphocytes (L), \% & $1.00^{\mathrm{b}}$ & $5.00^{\mathrm{a}}$ & $5.00^{\mathrm{a}}$ & \pm 0.471 \\
Mesophils (M), \% & $9.00^{\mathrm{a}}$ & $1.00^{\mathrm{b}}$ & $1.00^{\mathrm{b}}$ & \pm 0.333 \\
Eosinophils(E), \% & & &
\end{tabular}

$a, b$ and $c$ means in the same row with different superscripts are significantly $(P \leq 0.05)$ different.

$S E=$ Standard error

$* R 0$, control ration, $R 1$, with $20 \%$ broccoli by-product and $R 2$, with $40 \%$ broccoli by-product.

Coles et al. (1986) recorded that a total leukocyte count of $13.000 / \mu 1$ may represent a slight leukocytosis, whereas $20.000 / \mu \mathrm{l}$ would be indicative of a marked leukocytosis. An absolute neutrophil count of $5600 / \mu \mathrm{l}$ or greater is considered to be as absolute neutrophilia, whereas an absolute neutropenia occurs when the count falls below $700 / \mu$ l for sheep. The alternation in the leukocyte picture can be the consequence of a normal physiologic response or a disease condition. The general causes of leukocytosis other than physiological status are generalized/ localized infections, intoxication, including these produced by metabolic disturbances, chemical, drugs, venoms...etc. In perspective, the dietary antioxidants (Vit.E and C) those considered as a vital components in broccoli by-product, could be affected significantly in which they were stimulate some characteristic changes in the pattern of total leukocytes and its fractions ((Lymphocytes, Eosinophils, Neutrophils, Basoophils and Mesophils), as reported by (Kamal et al., 2012). Definitely, leukocyte count is an important index for diagnosis of the health status and problems, and may be adopted for assessing physiological changes related to production stresses, pregnancy and immune response (Bike, 2003).

\section{Rumen parameters}

Data in Table (6) revealed that rumen $\mathrm{pH}$ value and TVFAs concentration were increased $(\mathrm{P}<0.05)$ and concentration of $\mathrm{NH} 3-\mathrm{N}$ was decreased $(\mathrm{P}<0.05)$ with increasing of broccoli meal introduced compared with the (control) group. These significant results may be due to the glucosinolates content that are represent an important class of organic compounds includes sulfur and 
nitrogen in broccoli by-product which submit the digestion gastrointestinal conditions as $\mathrm{pH}$, temperature, enzyme and chemical conditions as observed by Vallej et al. (2004). On the other hand, Yi et al. (2015) concluded that replacing concentrate mixture with $20 \%$ pelletized broccoli by-products had no adverse effects on rumen fermentation, but increased milk production numerically and increased milk fat content significantly in lactating dairy cows. Presumably, large quantities of by-products are used in the ruminant's diet in agro-industrial areas (Gasa et al., 1989).

However, little is known about their fermentation pattern in the rumen and a better understanding of their digestion and products of fermentation is necessary in order to properly balance their introduction into the diet (Durand et al., 1988). Potentially, ruminants play an essential role due to their capacity to digest the fiber fractions of feeds by the rumen microorganisms and efficiently convert by-products that would be disposed in the environment into animal products for human consumption (Grasser et al., 1995).

Table (6): Rumen activity of lambs fed the experimental rations.

\begin{tabular}{lcccc}
\hline \multirow{2}{*}{ Item } & \multicolumn{3}{c}{ Experimental rations } & \multirow{2}{*}{ RE } \\
\cline { 2 - 4 } & $\mathrm{R} 0$ & $\mathrm{R} 1$ & $\mathrm{R} 2$ & \\
\hline Rumen $\mathrm{pH}$ value & $6.21^{\mathrm{b}}$ & $6.59^{\mathrm{a}}$ & $6.81^{\mathrm{a}}$ & \pm 0.073 \\
$\mathrm{NH} 3(\mathrm{mq} / \mathrm{dl})$ & $18.46^{\mathrm{a}}$ & $17.10^{\mathrm{b}}$ & $16.47^{\mathrm{c}}$ & \pm 0.124 \\
TVFAs (mq/dl) & $11.27^{\mathrm{c}}$ & $11.79^{\mathrm{b}}$ & $12.32 .^{\mathrm{a}}$ & \pm 0.115 \\
\hline
\end{tabular}

$a, b$ and $c$ means in the same row with different superscripts are significantly $(P \leq 0.05)$ different.

$S E=$ Standard error

$* R 0$, control ration, $R 1$, with $20 \%$ broccoli by-product and $R 2$, with $40 \%$ broccoli by-product.

\section{CONCLUSION}

Replacement at $40 \%$ level of broccoli wastes by lucerne hay may be useful as it improved nutrient digestibility. Moreover, broccoli wastes appear to reflect a good hepatic function and correlate very well with high immunity as well as the best results regarding growth performance of lambs. So, $40 \%$ broccoli could be safely, successfully and economically used for lamb.

\section{REFERENCES}

A.O.A.C. (1990). Association of Official Analytical Chemists Official Methods of Analysis.15th Ed. Washington D.C.

Ahuja, I.; B.H. Borgen; M. Hansen; B.I. Honne; C. Müller; J. Rohloff; J.T. Rossiter and A.M. Bones (2011). Oilseed rape seeds with ablated defense cells of the glucosinolate-myrosinase system. Production and characteristics of double haploid MINELESS plants of Brassica napus L. J. Exp. Bot., 62(14): 4975-93.

Aiso, I.; H. Inoue; Y. Seiyama and T. Kumano (2014). Compared with the intake of commercial vegetable juice, the intake of fresh fruit and Komatsuna (Brassica rapa L. Var. perviridis) juice mixture reduces serum cholesterol in middle-aged men: a randomized controlled pilot study. Lipid health Dis., 13:102.

Allian, C. C.; L. S. Poon; C. S. G. Chan and W. Richmond (1974). Enzymatic determination of total serum cholesterol. Clin. Chem., 20:470-475.

Alpuche-Solis, A.G. and O. Paredes-Lo'pez (1992). Assessment of glucosinolates in broccoli by three different methodologies. J. Food Biochem., 16(5):265_275.

Armstrong, W.D. and C.W. Carr (1964). Physiological Chemistry:Laboratory directions 3rd ed, Burgers Publishing Co. Minneapolis, Minnesota, USA.

Assayed, M.E. and A.M. Abd El-Aty (2009). Cruciferous plants: phytochemical toxicity versus cancer chemo protection. Mini. Rev. Med. Chem., 1; 9(13): 1470-1478. 
Azza, M. Kamal.; Ibtisam, M. Azzam; Y.H. Hafez; A.Y. El-Badawi and Faten, F. Abou-Ammou (2012). Nutritional evaluation of a Fungal-Yeast probiotic fortified with natural antioxidants on performance of sheep. 3- Impact on body temperature, internal antioxidants, haematological and histopathological changes of local sheep raised under different climatic conditions. Egypt. J. Nutr. And Feeds, 15 (2):295-310.

Bike, D.E. (2003). Influence of selenium and iodine supplementation on thyroid hormone concentrations in the blood serum of sheep. Medycyna weterynary, 59(12): 1126-1129.

Charlotte, N. Armah.; Christos Derdemezis; Maria, H. Traka; Jack, R. Dainty; Joanne, F. Doleman; Shikha Saha; Wing Leung; John, F. Potter; Julie, A. Lovegrove and Richard F. Mithen (2015). Diet rich in high glucoraphanin broccoli reduces plasma LDL cholesterol: Evidence from randomized controlled trials. Molecular. Nutr. Food Res., 59,918-926.

Coles, E.H. (1986). Vetrinary Clinical Pathology. 4thed., W.B. Saunders Company. Philadelphia, London, Toronto, Mecclco City, Rio de Janeiro, Syney and Tokyo.

Conway, E.F (1963). Modification Analysis Method for Determining Ammonia in Compound. Analytical compound and volumetric error. Rev. ED. Look Wood, London.

Cox-Ganser J.M.; G.A. Jung; R.T. Pushkin and R.L. Reid (1994). Evaluation of Brassica in grazing systems for sheep: II. Blood composition and nutrient status. J. Anim. Sci., 72: 1832-2842.

Craig, W. J. (1999). Health-promoting properties of common herbs. American Journal of Clinical nutrition, 70, 3: 491-499.

Doumas, B.; W. Wabson and H. Biggs (1971). Albumin standareds and measurement of serum with bromocresol green. Clin. Chem. Acta, 31:87.

Duncan, D.B. (1955). Multiple ranges and multiple F- test. Biometric, 11:1-42.

Durand, M.; C. Dumay; P. Beaumatin and M.T. Moral (1988). Using of the rumen simulation technique (RUSITEC) to compare microbial digestion of various by-products. Anim. Feed Sci. Technol., 22:197-204.

Gasa, J.; C. Castrillo; M.D. Baucells and J.A. Guada (1989). By-product from the canning industry as feedstuff for ruminants: Digestibility and its prediction from chemical composition and laboratory bioassay. Anim. Feed Sci. and Technol., 25:67-77.

Gerendas, J.; S. Breuning; T. Stahl; V. Mersh-Sundermann and K.H. Muhling (2008). Isothiocyanate concentration in Kohlrabi (Brassica oleracea L. Var. gongylodes) plants as influenced by sulfur and nitrogen supply. J. Agric. Chem., 24,56 (18): 8334- 8342.

Grasser, L.A.; J.G. Fadel; I. Granett and E.J Depeters (1995). Quantity and economic importance of nine selected by-products used in california dairy rations. J. Dairy Sci., 78:962-971.

Griminger, P. (1986). Lipid Metabolism in "AVIAN PHYSIOLOGY" Edited by P.D. Sturkie. 4th ed. Springer-Verlag, Inc., New Work, NY.

Henry, R. J.; D. C. Cannon and W. Winkelman (1974). Clinical chemistry principals and techniques, 11th ed. New York: Happer and Row Publishers.1629.

Hsu, F.C.; M. Wirtz; S.C. Heppel; J. Bogs; U. Krämer; M.S. Khan; A. Bub; R. Hell and T. Rausch (2011). Generation of Se-fortified broccoli as functional food: impact of Se fertilization on $\mathrm{S}$ metabolism. Plant Cell Environ., 34(2): 192-207.

Hu, C.H.; A.Y. Zuo; D.G. Wang; H.Y. Pan; W.B. Zheng; Z.C. Qian and X.T. Zou (2011). Effects of broccoli stems and leaves meal on production performance and egg quality of laying hens. Animal Feed Science and Technology, 170:117-121.

Hu, C.H.; D.G. Wang; H.Y. Pan; W.B. Zheng; A.Y. Zuo and J.X. Liu (2012). Effects of broccoli stem and leaf meal on broiler performance, skin pigmentation, antioxidant function and meat quality. Poultry Sci., 91:2229-2234.

Ibrahim, Sh. A.M.; H.A.A. Omer; F.A.F. Ali and R.I. El-Kady (2011). Broccoli By-Products as a Partial Replacement of Lucerne Hay in Rabbit Diets Containing Different Levels of Protein. AmericanEurasian J. Agric. \& Environ. Sci., 11 (5): 685-696.

Kummer, N.; U.B. Snigh and D.N. Verma (1981). Effect of different level of dietary protein and energy on growth of male buffalo calves. Indian J. Anim. Sci., 51: 513. 
Madhu and Anita Kochhar (2014). Proximate composition, available carbohydrates, dietary fibre and anti-nutritional factors of Broccoli (Brassica oleracea l var. Italica plenca) leaf and floret powder. Biosci. Disc., 5(1):45-49.

Madrid, J.; M. Dolores-Megias and F. Hernandes (2002). In vitro determination of ruminal dry matter and cell wall degradation and production of fermentation end-products of various by-products. Anim. Res., 51:189-199.

Mahro, B. and M. Timm (2007). Potential of biowaste from the food industry as a biomass resource. Eng. Life Sci., 7(5):457-468.

Mitruka, B.M. and H.M. Rawnsley (1977). Clinical, biochemical and hematological reference values in normal experimental animals. Masson Publishing, New York, USA.

Mueller, K.; Nicole M. Blum; H. Kluge; R. Bauerfeind; Julia Froehlich; Anneluise Mader; Karola R. Wendler and Andreas S. Mueller (2012). Effects of broccoli extract and various essential oils on intestinal and faecal microflora and on xenobiotic enzymes and the antioxidant system of piglets. Open J.of Anim. Sci., 2 (2):78-98.

NRC (1989). Nutrient requirement of Dairy Cattle 7th Ed. National Research Council. National Academy Press. Washington, DC., USA.

Olga, N. Campas-baypoli.; Dalia I. Sánchez-machado; Carolina Bueno-solano; Jose A. Núñez-gastélum; C. Reyes-moreno and J. López-cervantes (2009). Biochemical composition and physicochemical properties of broccoli flours. Int. J. Food Sci. and Nutr., 60(54):163-173.

Omirou, M.D.; K.K. Papadopoulou; I. Papastylianou; M. Constantinou; D.G. Karpouzas; I. Asimakopoulos and C. Ehaliotis ( 2009). Impact of nitrogen and sulfur fertilization on the composition of glucosinolates in relation to sulfur assimilation in different plant organs of broccoli. J. Agric Food Chem., 28, 57(20): 9408-9417.

Patton, C. J. and S. R. Crouch (1977). Spectrophotometric and kinetics investigation of the berthelot reaction for the determination of ammonia. Anal. Chem., 49:464 - 469.

Reitman, S. and S. Frankel (1957). A colorimetric method for determination of serum glumaticoxaloacetic and glutamic pyruvic transaminases . Ann. J. of clinical pathol., 28 (1) 56-63.

SAS Institute, Inc (1999). SAS. User's Guide: Statistics, SAS Institute., Inc. Cary, NC.

Snedecor, G.W. and W.G. Cochran (1980). Statistical Methods"' 6th ed., Iowa State University Press. Ames, Iowa, USA.

Stroev, E. A. (1989). Biochemistry Text Book, MIR Publishers, MOSCOW.

Tripathi, M.K. and A.S. Mishra (2007). Glucosinolates in animal nutrition: a review. Anim. Feed Sci. Technol., 132: 1-27.

USDA, (2011). Nutritive value of broccoli leaves (cited from http://nutrition data.self.com/facts/vegetables-and-vegetables products/broccoli/leaves).

Vallejo, F.; A. Gil-Izquierdo; A. Pérez-Vicente and C. García-Viguera (2004). In vitro gastrointestinal digestion study of broccoli inflorescence phenolic compounds, glucosinolates and vitamin C. J. Agric. Food Chem., 14, 52(1): 135-138.

Wahlefeled, A.W. (1974).Triglycerides determination after enzymatic hydrolysis. P:1831. In H.U. Bergmeyes, ed Methods of enzymatic analysis .varly chemic. Weinheim and academic press. Inc., New york and London 4 vols.

Warner, A.C.I. (1964). Production of volatile fatty acids in the rumen, method of measurements. Nut. Abst. and Rev., 34: 339.

Yi, X.W.; F. Yang; Y. Chen; J.K. Wang and J.X. Liu (2008). Feasibility of broccoli residues as protein source for ruminants. Proc. Of 13th AAAP, Animal Sci. Cong., 22-26, Hanoi, Vietnam.

Yi, X.W.; F. Yang; Y. Chen; J.X. Liu and J.K Wang (2015). Effects of replacement of concentrate mixture by broccoli by-products on lactating performance in dairy cows. Asian-Australas J. Anim. Sci., 28(10):1449-1453. 


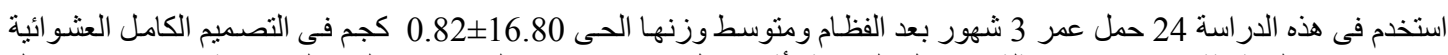

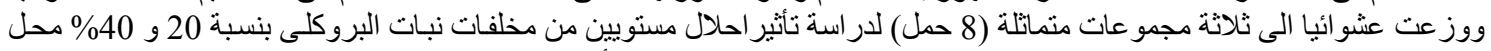

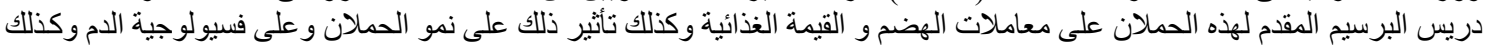

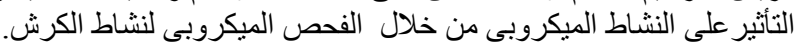

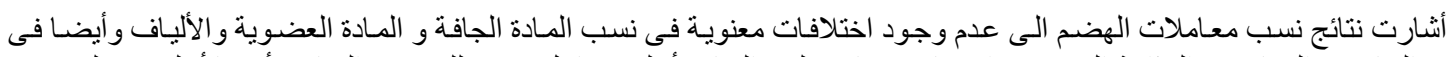

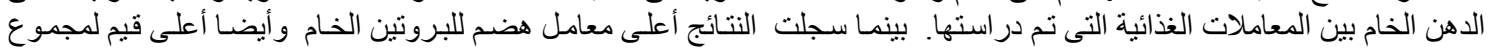

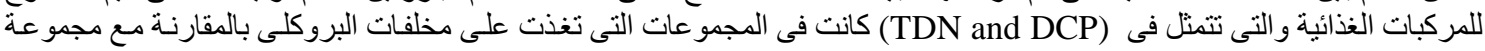
الكنترول.

كما اشارت النتائج الى أن المعاملات التجريبية الدختبرة عند مستوى20 \% أدى الى زيادة (P<0.05) معنوية فى معامل هضم ال بالمقارنة مع المجمو عتين الاخرتين.

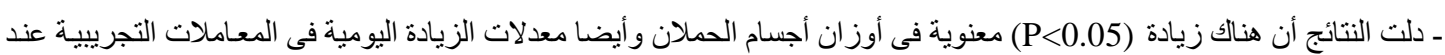
مستوى 20 و 40\% من مخلفات البروكلى بالمقارنة مع مجموعة الكنترول خلام الكال الفترة التجربة.

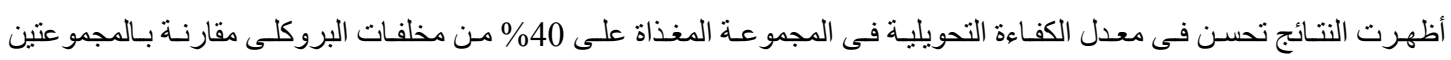

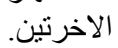

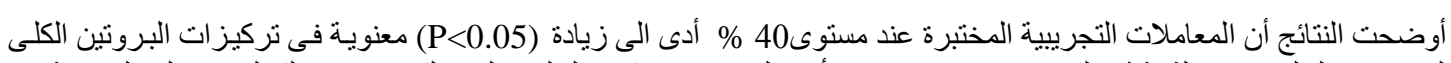

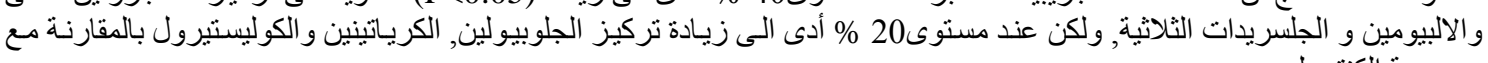

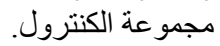

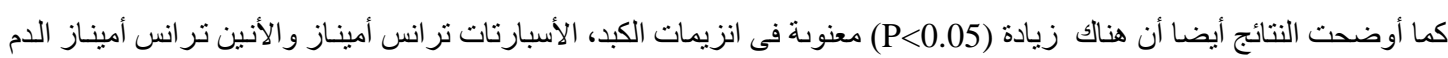

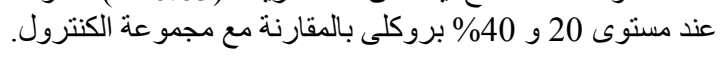

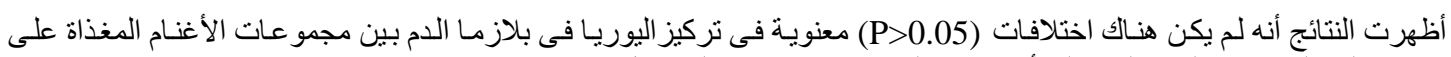

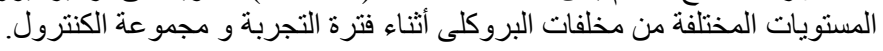

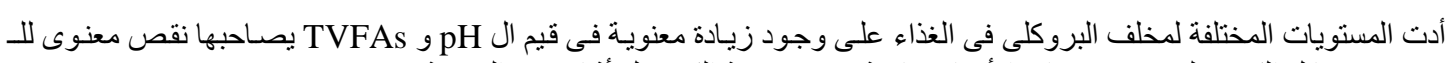

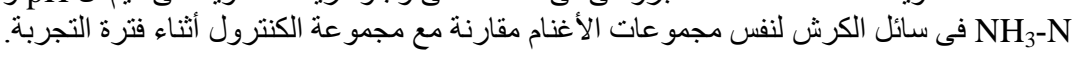

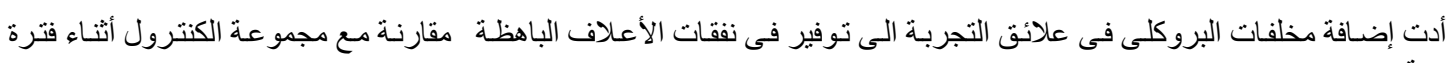

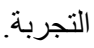
نخلص من هذه النتائج أنه بمكن استبدال مخلفات البروكلى عند مستوى 40٪ من دربس البرسيم في علائق الاغنام. 